\title{
Dental erosion in French adolescents
}

\author{
Michèle Muller-Bolla ${ }^{1,2^{*}}$, Frédéric Courson ${ }^{2,3}$, Violaine Smail-Faugeron ${ }^{2,3}$, Thibault Bernardin ${ }^{1}$ and \\ Laurence Lupi-Pégurier ${ }^{1}$
}

\begin{abstract}
Background: Since the 2000s, different epidemiological studies focusing on the prevalence or the aetiology of DE in adolescents recognised them as an at-risk population due to their eating behaviours. None was carried out in French adolescents.

The primary objective of this study was to assess the prevalence of dental erosion (DE) using the total BEWE score among adolescents in the department of Alpes Maritimes, France. The secondary objectives were to observe changes in prevalence estimates depending on both the cutoffvalue of total BEWE score with different teeth/dental surfaces examined, and to identify the related risk factors.
\end{abstract}

Methods: A cross-sectional study in a multistage random sample of 339 14-yr-old schoolchildren was carried out in 2014. The children completed a self-administered questionnaire concerning diet and oral habits. Caries was assessed with ICDAS-II (International Caries Detection and Assessment System-II) criteria and erosion with BEWE (Basic Erosive Wear Examination) index. The total BEWE score was calculated to assess the DE prevalence with two cutoff values (3 and 1). Data were analysed using descriptive statistics and logistic regression models.

Results: The 331 children were aged $14.4 \pm 0.5$ years. The DE prevalence was $39 \%$ using a total BEWE score $\geq 3$. With a cutoff total BEWE score of 1 (at least one affected tooth), the prevalence varied from 3.9 to $56.8 \%$ depending on the teeth/surfaces that were used for the analysis. The DE prevalence, assessed with only first molars and maxillary incisors, was about $54 \%$. The risk factors for DE (total BEWE score $\geq 3$ ) were daily consumption of acidic beverages (OR: 4.0; $95 \%$ Cl: 2.1-7.6) and acidic sweets (OR: 3.2; 95 \% Cl: 1.2-8.0), low socio economic category (OR: 2.4; 95 \% Cl: 1.1-5.0) and visible dental biofilm (OR: 2.0; $95 \%$ Cl: 1.2-3.4).

Conclusion: Depending on the method chosen, the prevalence varied from 3.9 to $56.8 \%$ among these adolescents. Thus, a consensus on choice of index, teeth to examine and age at assessment is necessary to standardise measurement of DE prevalence.

\section{Background}

Dental erosion (DE) is a non-carious lesion consisting of progressive and irreversible loss of dental hard tissue due to the chemical process of acid dissolution that does not involve bacterial plaque acid [1,2]. Its overall clinical appearance may also involve a frictional component, such as abrasion or attrition, particularly in older age groups. Since the 2000s, different epidemiological studies focusing on the prevalence or the aetiology of DE in adolescents recognised them as an at-risk population

\footnotetext{
* Correspondence: michele.muller@unice.fr

${ }^{1}$ Dental Faculty, University Nice Sophia Antipolis. CHUN, Nice, France

${ }^{2}$ URB2i - EA 4462, University Paris Descartes, Montrouge, France

Full list of author information is available at the end of the article
}

due to their eating behaviours. The studies were carried out in the Americas [3-14], Arabian countries [15-23], an Asian country $[24,25]$ and in Western Europe [2, 26-35]. The prevalence of DE ranged from 7 to $95 \%$ and, except in two studies, the extension of severe erosion into dentine was usually infrequent $[11,16]$ (Table 1). The wide variation of prevalence in teenagers is suggestive of the difficulty in finding a unanimously accepted index among researchers for measuring and detecting erosive lesions. A recent systematic review estimated an overall worldwide prevalence of tooth erosion of $30 \%$ (95 \% CI: 24-37) by mixing different clinical indices and without specifying the teeth examined. Futhermore, the review included population-based studies in 
Table 1 Prevalence of dental erosion in adolescents (12-16 years-old) assessed on a population-based samples (prevalence studies published since 2000)

\begin{tabular}{|c|c|c|c|c|c|c|c|c|}
\hline Authors & Year & Country (Area) & Age (years) & Sample size & Erosion/Wear & Index used & $\begin{array}{l}\text { Permanent teeth } \\
\text { (surfaces) Examined }\end{array}$ & Prevalence (\%) \\
\hline El Karim et al. [23] & 2007 & Sudan (Khartoum) & $12-14$ & 157 & Erosion & $\begin{array}{l}\text { Smith and Knight Tooth Wear Index } \\
\text { (TWI) [51]. }\end{array}$ & UI $(B, P)$ & $66.9 \%$ \\
\hline Hamasha et al. [15] & 2014 & $\begin{array}{l}\text { Jordan (Amman, } \\
\text { libid, Al-Karak) }\end{array}$ & $12-14$ & 3812 & Erosion & $\begin{array}{l}\text { TWI [51] modified by Millward et al. [52]: } \\
0 \text { (B/L/O/I) No loss of enamel surface } \\
\text { characteristics. } \\
1 \text { (B/L/O/I) Loss of enamel surface } \\
\text { characteristics. } \\
2 \text { (B/L/O) Loss of enamel, visible dentine } \\
\text { for less than } 1 / 3 \text { of the surface. } \\
2 \text { (I) Loss of enamel just exposing dentine. } \\
3 \text { (B/L/O) Loss of enamel, visible dentine } \\
\text { for }>1 / 3 \text { of the surface. } \\
3 \text { (I) Loss of enamel and substantial loss } \\
\text { of dentine. } \\
4 \text { (B/L/O) Complete loss of enamel, or } \\
\text { pulp exposure, or exposure of secondary } \\
\text { dentine. } \\
4 \text { (I) Pulp exposure or exposure of } \\
\text { secondary dentine. }\end{array}$ & $\begin{array}{l}\text { All permanent teeth } \\
\text { (all surfaces) }\end{array}$ & $32.2 \%$ \\
\hline Al Majed et al. [16] & 2002 & $\begin{array}{l}\text { Saudi Arabia } \\
\text { (Riyadh) }\end{array}$ & $12-14$ & 862 & Erosion & $\begin{array}{l}\text { Modified TWI derived from the } 1998 \\
\text { United Kingdom Adult Dental Health } \\
\text { Survey [53]: } \\
0 \text { No obvious wear facets in enamel. } \\
1 \text { Marked wear facets in enamel. Enamel } \\
\text { only, Loss of surface characterisation. }\end{array}$ & $\mathrm{UI}(\mathrm{B}, \mathrm{P}), \mathrm{M} 1(\mathrm{O})$ & $\begin{array}{l}95 \% \text { (DE in at least } \\
\text { one tooth) } \\
26 \% \text { (DE into dentine } \\
\text { or into pulp) }\end{array}$ \\
\hline $\begin{array}{l}\text { McGuire et al. [3] } \\
\text { Okunseri et al. [13] }\end{array}$ & $\begin{array}{c}2009 \\
2011\end{array}$ & $\begin{array}{l}\text { United States } \\
\text { (NHANES) }\end{array}$ & $13-19$ & 1962 & Erosion & $\begin{array}{l}2 \text { Wear into dentin, dentin exposed } \\
\text { occlusally/incisally. Loss of enamel } \\
\text { exposing dentine. } \\
3 \text { Extensive wear into dentin, greater than } \\
2 \mathrm{~mm}^{2} \text { of exposed dentin, pulp exposure. } \\
\text { Loss of enamel and dentin resulting in } \\
\text { pulpal exposure. }\end{array}$ & $\begin{array}{l}\text { Incisors, canines, } \\
\text { M1 (O) }\end{array}$ & $\begin{array}{l}45.9 \% \text { (DE in at least } \\
\text { one tooth): } \\
13-14 \text { year-old: } 39.6 \% \\
16-17 \text { year-old: } 44.5 \%\end{array}$ \\
\hline $\begin{array}{l}\text { Bardsley et al. [26] } \\
\text { Milosevic et al. [27] }\end{array}$ & 2004 & $\begin{array}{l}\text { Nord west England } \\
\text { (Preston) }\end{array}$ & 14 & 2385 & Wear & $\begin{array}{l}\text { Simplified version of TWI dichotomised as } \\
\text { the presence or absence of dentinal }\end{array}$ & $\begin{array}{l}\text { Incisors, canines, } \\
\text { M1 (O) }\end{array}$ & $53 \%$ \\
\hline Bardolia et al. [31] & 2010 & UK (Isle of Man) & $13-14$ & 629 & Erosion & $\begin{array}{l}\text { exposure (S-TWI) (1984): } \\
0 \text { No wear into dentin. } \\
1 \text { Dentine just visible (including cupping) }\end{array}$ & $\begin{array}{l}\text { Incisors, canines, } \\
\text { M1 (O) }\end{array}$ & $\begin{array}{l}51 \% \text { ( } 20 \% \text { if exclusion } \\
\text { of incisal edge wear) }\end{array}$ \\
\hline Abu-Ghazaleh et al. [22] & 2013 & Jordan (Amman) & $15-16$ & 1602 & Wear & $\begin{array}{l}\text { or dentine exposed for less than } 1 / 3 \text { of } \\
\text { surface. } \\
2 \text { Dentin exposure greater than } 1 / 3 \text { of } \\
\text { surface. } \\
3 \text { Complete loss of enamel on a surface, } \\
\text { exposure of pulp or secondary dentin. }\end{array}$ & $\begin{array}{l}\text { Incisors, canines, } \\
\text { M1 (O) }\end{array}$ & $51 \%$ \\
\hline
\end{tabular}


Table 1 Prevalence of dental erosion in adolescents (12-16 years-old) assessed on a population-based samples (prevalence studies published since 2000) (Continued)

\begin{tabular}{|c|c|c|c|c|c|c|c|c|}
\hline $\begin{array}{l}\text { Dugmore et al. [32] } \\
\text { Dugmore et al. [28] }\end{array}$ & $\begin{array}{l}2003 \\
2004\end{array}$ & $\begin{array}{l}\text { UK (Leicestershire, } \\
\text { Rutland) }\end{array}$ & 1214 & $\begin{array}{l}17531308 \\
\text { re-examined }\end{array}$ & Erosion & \multirow{7}{*}{$\begin{array}{l}\text { Index of O'Brien [32]. } \\
\text { Depth: } \\
0 \text { Normal enamel. } \\
1 \text { Loss of enamel surface characteristics. } \\
2 \text { Loss of enamel exposing dentine } \\
3 \text { Loss of enamel and dentine with pulp } \\
\text { exposure. } \\
\text { Area: } \\
1 \text { Less than one third of surface involved. } \\
2 \text { Between one and two thirds of surface } \\
\text { involved. } \\
3 \text { More than two thirds of surface } \\
\text { involved. } \\
\text { Modified scale of Lussi by Van Rijkom [54]: } \\
0 \text { No visible smooth wear. } \\
1 \text { Slight smooth enamel wear, surface } \\
\text { with silky-shining, 'melted' appearance. } \\
2 \text { Deep smooth enamel wear, dentine is } \\
\text { shining through (light yellow). } \\
3 \text { Smooth wear into dentine on L/P or O } \\
\text { surfaces, or less than one-half of B } \\
\text { surfaces (yellow). } \\
4 \text { Smooth wear into dentine on more } \\
\text { than one-half of B surfaces. }\end{array}$} & Incisors, M1 & $\begin{array}{l}12 \text { year-old: } 59.7 \% \\
(2.7 \% \text { exhibiting } \\
\text { exposed dentine) } \\
14 \text { year-old: } 64.1 \% \\
\text { ( } 56.3 \% \text { at } 12 \text { year-old) }\end{array}$ \\
\hline Sanhouri et al. [18] & 2010 & Sudan (Khartoum) & $12-14$ & 1138 & Wear & & $\begin{array}{l}\text { All permanent teeth } \\
\text { (all surfaces) }\end{array}$ & $74 \%$ \\
\hline Gurgel et al. $[9,10]$ & 2011 & Brazil (Bauru) & 12,16 & 414 & Erosion & & $\mathrm{UI}(\mathrm{B}, \mathrm{P}), \mathrm{M} 1(\mathrm{O})$ & $\begin{array}{l}20 \% \text { (withoutloss of } \\
\text { dentine) }\end{array}$ \\
\hline Habib et al. [12] & 2013 & $\begin{array}{l}\text { United States } \\
\text { (Kansas city) }\end{array}$ & 12 & 218 & Erosion & & $\mathrm{UI}(\mathrm{B}, \mathrm{P})$ & $10 \%$ \\
\hline Van Rijkom et al. [30] & 2002 & $\begin{array}{l}\text { The Netherlands } \\
\text { (The Hague) }\end{array}$ & $\begin{array}{l}10-13 \\
15-16\end{array}$ & $\begin{array}{l}345 \\
400\end{array}$ & Erosion & & $\begin{array}{l}\text { All permanent teeth } \\
\text { (all surfaces) }\end{array}$ & $\begin{array}{l}3 \% \text { of } 10-13 \text { year-olds } \\
30 \% \text { of } 15-16 \text { year-olds }\end{array}$ \\
\hline Truin et al. [33] & 2005 & $\begin{array}{l}\text { The Netherlands } \\
\text { (The Hague) }\end{array}$ & 12 & 324 & Erosion & & UI, UC (P); M1 (O) & $24 \%$ \\
\hline El Aïdi et al. [34] & 2008 & $\begin{array}{l}\text { The Netherlands } \\
\text { (Oss) }\end{array}$ & $10-12$ & 622 & Erosion & & $\begin{array}{l}\text { All permanent teeth } \\
\text { (all surfaces) }\end{array}$ & $\begin{array}{l}32.2 \% \text { (deep enamel } \\
\text { erosion: } 1.8 \% \text { ) }\end{array}$ \\
\hline Arnadottir et al. [29] & 2003 & Iceland (Reykjavik) & 15 & 278 & Erosion & $\begin{array}{l}\text { Modified scale of Lussi (1991): } \\
0 \text { No erosion. }\end{array}$ & $\begin{array}{l}\text { All permanent teeth } \\
\text { (all surfaces) }\end{array}$ & $21.6 \%$ \\
\hline Arnadottir et al. [2] & 2010 & Iceland & 12,15 & 1507 & Erosion & $\begin{array}{l}1 \text { Loss of surface enamel, dentine not } \\
\text { involved (anterior teeth), enamel erosion } \\
\text { on cusp tips that cannot be attributed to } \\
\text { attrition (posterior teeth). } \\
2 \text { Erosion extending into dentine. } \\
3 \text { Extending close to pulp (pulp chamber } \\
\text { visible). }\end{array}$ & $\begin{array}{l}\text { All permanent teeth } \\
\text { (all surfaces) }\end{array}$ & $\begin{array}{l}15.7 \% \text { of } 12 \text {-year-olds } \\
(n=757) \\
30.7 \% \text { of } 15 \text {-year-olds } \\
(n=750)\end{array}$ \\
\hline Peres et al. [7] & 2005 & Brazil (Joaçaba) & 12 & 391 & Erosion & Dental erosion index of O'Sullivan [55]. & Ul & $13 \%$ \\
\hline Correr et al. [4] & 2009 & $\begin{array}{l}\text { Brazil (Piracicaba, } \\
\text { São Paulo) }\end{array}$ & 12 & 389 & Erosion & $\begin{array}{l}\text { Grade of severity: } \\
0 \text { Normal enamel. } \\
1 \text { Matte appearance of the enamel surface }\end{array}$ & $\mathrm{UI}, \mathrm{M} 1$ & $26 \%$ \\
\hline Wang et al. [24] & 2010 & China (Guangzhou) & $12-13$ & 1499 & Erosion & with no loss of contour. & Incisors, M1 & $27.3 \%$ \\
\hline Vargas-Ferreira et al. [11] & 2011 & Brazil (Santa Maria) & $11-14$ & 870 & Erosion & 3 Loss of enamel with exposure of dentin & $\mathrm{UI}, \mathrm{M} 1$ & $7.2 \%$ \\
\hline Kumar et al. [17] & 2013 & $\begin{array}{l}\text { Karnataka, South } \\
\text { India }\end{array}$ & $11-14$ & 605 & Erosion & $\begin{array}{l}\text { (ADJ visible). } \\
4 \text { Loss of enamel and dentin beyond ADJ. }\end{array}$ & $\begin{array}{l}\text { All permanent teeth } \\
\text { (all surfaces) }\end{array}$ & $8.9 \%$ \\
\hline Aguiar et al. [8] & 2014 & $\begin{array}{l}\text { Brazil (Campina } \\
\text { Grande) }\end{array}$ & $15-19$ & 675 & Erosion & $\begin{array}{l}\text { exposure of pulp. } \\
\text { Area of surface affected by erosion: } \\
\text { Code- Less than half of the surface affected. } \\
\text { Code + More than half of the surface } \\
\text { affected. }\end{array}$ & $\mathrm{UI}, \mathrm{M} 1$ & $21 \%$ \\
\hline
\end{tabular}


Table 1 Prevalence of dental erosion in adolescents (12-16 years-old) assessed on a population-based samples (prevalence studies published since 2000) (Continued)

\begin{tabular}{|c|c|c|c|c|c|c|c|c|}
\hline $\begin{array}{l}\text { Auad et al. [5] } \\
\text { Waterhouse et al. [6] }\end{array}$ & $\begin{array}{l}2007 \\
2008\end{array}$ & $\begin{array}{l}\text { South east Brazil } \\
\text { (TrêsCorações) }\end{array}$ & $13-14$ & 458 & Erosion & \multirow{2}{*}{$\begin{array}{l}\text { Criteria used in UK National Diet and } \\
\text { nutrition survey [56]: } \\
0 \text { Normal. } \\
1 \text { Enamel only. Less than one third of } \\
\text { surface involved. } \\
2 \text { Enamel and dentine. One third up to } \\
\text { two thirds of surface involved. } \\
3 \text { Enamel, dentine and pulp. Two thirds } \\
\text { or more of surface involved. }\end{array}$} & UI (B/P), M1 (O) & $\begin{array}{l}34.1 \% \text { (no evidence of } \\
\text { erosion affecting } \\
\text { dentine) }\end{array}$ \\
\hline Huew et al. [19-21] & 2011 & Libya (Benghazi) & 12 & 791 & Erosion & & UI (B/P), M1 (O) & $40.8 \%$ \\
\hline Margaratis et al. [35] & 2011 & Greece (Attica) & $14-16$ & 502 & Erosion & \multirow{3}{*}{$\begin{array}{l}\text { BEWE scoring system [46]: } \\
0 \text { No erosive tooth wear. } \\
1 \text { Initial loss of surface texture. } \\
2 \text { Distinct defect; hard tissue loss }<50 \% \\
\text { of the surface area. } \\
3 \text { Hard tissue loss } \geq 50 \% \text { of the surface } \\
\text { area. }\end{array}$} & $\begin{array}{l}\text { All permanent teeth } \\
\text { (all surfaces) }\end{array}$ & $\begin{array}{l}58 \% \text { (BEWE >0) } \\
\text { If S-TWI on incisors, } \\
\text { M1(O): } 51.6 \%\end{array}$ \\
\hline Zhang et al. [25] & 2014 & China (Hong Kong) & 12 & 600 & Erosion & & $\begin{array}{l}\text { All permanent teeth } \\
\text { (all surfaces) }\end{array}$ & $\begin{array}{l}75 \%(B E W E>0) \text { but } \\
\text { no severe erosion } \\
(B E W E=3)\end{array}$ \\
\hline Alvarez Loureiro L. et al. [14] & 2015 & $\begin{array}{l}\text { Montevideo } \\
\text { (Uruguay) }\end{array}$ & 12 & 1136 & Erosion & & $\begin{array}{l}\text { All permanent teeth } \\
(B, P, O)\end{array}$ & $52.9 \%$ (BEWE >0) \\
\hline
\end{tabular}


the permanent teeth of children and adolescents aged 8-19 years [36].

When focusing on Europeans adolescents, the prevalence of DE has ranged from 18 to $64 \%[28,33]$ but no epidemiological study of DE has so far been carried out in France (Table 1). The prevalence of DE was only indirectly considered in the study of Bartlett et al. [37]; it focused on the prevalence of tooth wear in 18-35 yearold Europeans including France and six other countries. The index used to measure both severity and distribution of tooth wear was the Basic Erosive Wear Examination (BEWE), as recommended by different authors [1, 38-41] but the protocol did not consider all surfaces, just the buccal and lingual surfaces of all teeth [37]. Nevertheless early signs of erosion are often observed on the occlusal surfaces of molars [1]. The problem of which clinical index to use and which teeth and tooth surfaces to observe arises since many different methods are available in the literature (Table 1). Finally, no studies that address the risk indicators for DE in France have been found.

The primary objective of the present study was to assess the prevalence of DE using the total BEWE score in a sample of French adolescents. The secondary objectives were to observe changes in prevalence depending on both the cutoff value of total BEWE score on different teeth/dental surfaces examined, and to identify the related risk factors.

\section{Methods}

This cross-sectional survey was carried out in 2014 in the Alpes Maritimes (AM) department in the south-east of France. Ethical approval was obtained from the local ethics committee ("Comité Protection Personnes sud Méditerranée V”).

\section{Study population}

Alpes Maritimes is the 14th most densely populated department in France with 251 persons per sq km. It includes Nice, the fifth largest city in France. Four of the 71 public secondary schools are located in rural areas, the others are in urban areas where students enrolled in priority education schools (PES) (12.5\%) are of lower socioeconomic status than others.

\section{Sampling procedure}

A minimum sample size of 322 adolescents was required assuming prevalence of DE of $30 \%$ [42, 43], precision and level of statistical signification of 0.05 . We used a two-stage, stratified sampling method to obtain a representative sample of approximately 14yr-old adolescents from 8th grade high-schools by randomisation of the schools on the basis of geographic location (urban/rural) and socio-economic category (PES/not PES). A list of all the schools was obtained from the local education department. Firstly, a consent form to participate in the study was given to all of the parents prior to the dentist's visit to the randomised schools. Secondly, the children who were present on the day of the examination and for whom positive parental and personal consent was obtained were included. Children were excluded if they were not 14 years old during the school year or if they were currently wearing orthodontic appliances. Children affected by a hereditary or acquired dental structural abnormality were also excluded.

\section{Data collection}

The data were collected on the day of the examination using a self-completed questionnaire. This questionnaire was based on one used in previous studies that identified risk factors for DE [44] and included sociodemographic characteristics, dietary and oral health behaviours. The French version was first tested in 30 French 14-yr-olds and it was found to be comprehensible for this age group.

\section{Clinical examinations}

Before examination, with good lighting (Power-Spotlight, Bisico, France), the teeth were carefully cleaned (Happy morning brushes, Hager \& Werken, France) and dried (Trans'Care Max, Satelec group, Acteon equipment, France). Lesions were scored using the BEWE index $(0$ $=$ no erosion, $1=$ early enamel surface loss, $2=$ enamel and dentine surface loss $<50 \%, 3=$ surface loss $50 \%$ ) on all permanent tooth scoreable surfaces. With this scoring system, all teeth were examined, and the most severely affected surfaces (buccal/labial, occlusal, and lingual/palatal) in each sextant were recorded. Each subject obtained a total BEWE score that corresponded to the sum of the highest scores in the six sextants; and the prevalence of erosion was calculated on the basis of a total BEWE score $\geq 3$. The risk level of $\mathrm{DE}$ is low when the total score is between 3 and 8; medium, between 9 and 13; and high for a score of 14 and above [38, 39, 41]. Carious lesions were recorded using the ICDAS-II (International Caries Detection and Assessment System) advanced method on all scoreable surfaces of permanent teeth. Children were affected by dentinal lesions (ICDAS 4-6) or with both enamel and dentinal lesions (ICDAS 1-6) [45]. After the examination, the children received a card to take home reporting their dental needs.

All clinical examinations were carried out by a single examiner (TB) who was trained and calibrated by a paediatric dentist (MMB). A range of different levels of dental erosion was used in the calibration process, which was based on photographic images. Reliability was assessed through the Kappa test. 


\section{Statistical analysis}

Prevalence was estimated as the proportion that had a total BEWE score $\geq 3$ considering highest scores in sextants (primary outcome). The proportions with a total BEWE score $\geq 1$ on particular permanent teeth (incisors, canines, first molars) were secondary outcomes. Data analysis included comparisons of means and the Chisquared test to investigate the univariate associations between the dichotomous dependent variable DE (primary outcome) and a range of demographic, dietary and oral care variables. Independent variables which were associated with $\mathrm{DE}(p<0.1)$ were entered as candidate variables into a stepwise multiple logistic regression analysis. All the significant variables were ranked using a multivariable logistic regression analysis. Similar multivariable logistic regression analyses were tested, changing the cutoff value of the dependent variable (total BEWE score $\geq 1$ considering all surfaces). The level of statistical significance was set at 0.05 . In each classroom, one child chosen at random was examined twice one week later by the same examiner using the ICDAS-II advanced method and the BEWE index to measure intra-examiner reliability. The corresponding Kappa values assessed in 34 re-examined children one week later were respectively 0.8 (ICDAS-II) and 0.9 (BEWE). Data were analysed using SPSS19.0.

\section{Results}

Of the 495 subjects invited to participate, 143 did not return the parental consent, 3 were absent on the day of the visit dates and 18 were excluded. The 331 children were aged $14.4 \pm 0.5$ years. There were 174 girls and 157 boys included; $12.1 \%(n=40)$ were enrolled in PES and $5.1 \%(n=17)$ in rural schools.

The highest total BEWE score $\geq 3$ (cumulative score of all sextants) in our study was in the range 9-13 (medium risk level) for only one adolescent. When the total BEWE cutoff score was $\geq 3$, prevalence was $39 \%$ (primary objective). When the cut off value was 1, i.e. at least one tooth with signs of $\mathrm{DE}$, the prevalence depended on the dental surfaces observed. If only maxillary incisors were examined, as in the method used in some studies carried out in adolescents [7, 12, 23] (Table 1), the prevalence decreased from 39 to $3.9 \%$. Conversely, if first molars were examined in addition to the maxillary incisors, whatever the surfaces considered, the prevalence was about $54 \%$, close to $56.8 \%$ for all the surfaces examined on all permanent teeth (Table 2). These results depend on the distribution of the DE lesions. Light extension (BEWE 3-8) was more frequent in mandibular (16.9) compared with maxillary (9.0) teeth. The BEWE score 3 was found just once on the occlusal subsurface of the second maxillary right premolar
Table 2 Dental Erosion prevalence in a sample of French adolescents ( $n=331)$ according to the dental surfaces of permanent teeth examined

\begin{tabular}{lll}
\hline Dental surfaces examined & BEWE & Prevalence \\
\hline Maxillary incisors ${ }^{\text {a }}$ & Total BEWE $\geq 1$ & $3.9 \%$ \\
$\begin{array}{l}\text { Maxillary incisors and occlusal } \\
\text { surfaces of first molars }{ }^{b}\end{array}$ & Total BEWE $\geq 1$ & $54.4 \%$ \\
$\begin{array}{l}\text { Maxillary incisors and first molars } \\
\text { on all scorable surfaces }{ }^{c}\end{array}$ & Total BEWE $\geq 1$ & $54.4 \%$ \\
$\begin{array}{l}\text { Incisors and first molars }{ }^{d} \\
\text { Six upper and lower anterior teeth, } \\
\text { occlusal surfaces of first molars }\end{array}{ }^{\text {All teeth (all surfaces) }}{ }^{f}$ & Total BEWE $\geq 1$ & $55.0 \%$ \\
\hline
\end{tabular}

$\left.{ }^{\mathrm{a}}[7,12,23]{ }^{\mathrm{b}}[5,6,9,10,16,19-21]\right)^{\mathrm{c}}[4,8,11]{ }^{\mathrm{d}}[24,28,32]$,

e $[3,13,22,26,31],{ }^{f}[2,14,15,17,18,25,29,30,34,35]$.

BEWE Basic Erosive Wear Examination

and score 2 was found on occlusal surfaces of permanent molars and second premolars. First molars, and more particularly the lower ones, were the most affected teeth (Table 3). If we consider the results for each kind of tooth, $98.0 \%$ of the subjects with at least one second molar affected by DE presented also DE on the first molars. Second premolars were more often affected than both the first ones and the second molars.

The risk factors for DE (Total BEWE score $\geq 3$ ) were, in decreasing order, the consumption of acidic beverages and sweets, and the low socio-economic category of participants. Area of residence, the presence of carious lesions (ICDAS 1-6 or 4-6) and prolonged retention of drinks in the mouth were not significantly associated with erosive experience in adjusted logistic regression analyses; visible dental biofilm was only associated if lesions ICDAS 4-6 were included in the multivariable logistic regression analysis (Table 4). Thus the consumption of acidic beverages (OR: 4.0; 95 \% CI: 2.1-7.6) and sweets (OR: 3.2; 95 \% CI: 1.2-8.0), low socio-economic category (OR: 2.4; 95 \% CI: 1.1-5.0) and the presence of visible dental biofilm (OR: 2.0; 95 \% CI: 1.2-3.4) had an effect on the primary outcome. When changing the dependent variable by substitution of primary outcome with the total BEWE score $\geq 1$ considering all surfaces, independent variables which were entered as candidate variables into a stepwise multiple logistic regression analysis were different (Table 5). With this cutoff value, only acidic beverages (OR: 6.4; 95 \% CI: 2.9-14.0) and drinking method (OR: 3.5; $95 \%$ CI: 1.4-8.9) had an effect on the dependant variable.

\section{Discussion}

The prevalence of DE using a total BEWE score $\geq 3$ in a stratified sample of French adolescents was $39 \%$. This was within the confidence interval of the overall estimated 
Table 3 BEWE scores according to affected teeth in 331 subjects

\begin{tabular}{|c|c|c|c|c|c|c|c|c|c|c|c|c|c|c|c|}
\hline & & $17-27$ & $16-26$ & $15-25$ & $14-24$ & $13-23$ & $12-22$ & $11-21$ & $31-41$ & $32-42$ & $33-43$ & $34-44$ & $35-45$ & $36-46$ & $37-47$ \\
\hline \multirow[t]{3}{*}{ Score 1} & $B$ & $1(0.2)$ & $22(3.3)$ & $10(1.5)$ & $8(1.2)$ & $21(3.2)$ & $12(1.8)$ & $17(2.6)$ & $8(1.2)$ & $5(0.8)$ & $5(0.8)$ & $8(1.2)$ & $10(1.5)$ & $16(2.4)$ & $3(0.5)$ \\
\hline & $\mathrm{O}$ & $4(0.6)$ & $180(22.7)$ & 81 (12.2) & $13(2.0)$ & & & & & & & $32(4.8)$ & $133(20.1)$ & $237(35.8)$ & $43(6.5)$ \\
\hline & $L$ & & $3(0.5)$ & & $1(0.2)$ & $4(0.6)$ & $2(0.3)$ & $2(0.3)$ & & & $2(0.3)$ & & & $5(0.8)$ & \\
\hline \multirow[t]{3}{*}{ Score 2} & B & & & & & & & & & & & & & $1(0.2)$ & \\
\hline & $\mathrm{O}$ & $4(0.6)$ & $30(4.5)$ & $8(1.2)$ & & & & & & & & $1(0.2)$ & $17(2.6)$ & $93(14.1)$ & $10(1.5)$ \\
\hline & $L$ & & & & & & & & & & & & & & \\
\hline
\end{tabular}

prevalence of DE in European countries (33\%, $95 \%$ IC 25-42) and outside the confidence interval of the overall worldwide prevalence of DE of $30 \%$ (95\% IC: 24-37), both reported in a recent systematic review [36]. Except in the two studies carried out in the United States [3, 13, 14], prevalences in America ranged from 7.2 to $34.1 \%$ and were lower than in France [4-12] whereas the systematic review, which included fewer studies, did not indicate any significant difference between American and European countries [36]. Conversely, except for the two studies with equivalent rates [15, 17, 19-21], four descriptive studies carried out in Arab countries indicated a higher prevalence, ranging from 51 to $95 \%$ $[16,18,22,23]$. Finally, by increasing order of prevalence in European countries, France was situated between The Netherlands [30, 33, 34] and Iceland [2, 29], with rates around 20-30\%, and United Kingdom [26-28, 31, 32] or Greece [35] around 50-60\%.

This ranking by country must be considered with caution as the prevalence of DE in adolescents was studied using different clinical indices. As indicated in the systematic review of Salas et al. [36], the prevalences of DE assessed with O'Sullivan's or Lussi's modified scales were lower $[2,4,7,8,11,17,24,29,30,33,34]$ than in the present study using the total BEWE score. On the contrary, the prevalences of DE were higher with the Tooth Wear Index (TWI) modified three times (Table 1). One of them [31] easily explains these observations because this was dichotomised as the presence or absence of dentinal exposure $[22,26,27,31]$. In the present study, the erosive lesions involved mostly the enamel. Only the study of Hamasha et al. [15], that used the TWI modified by Millward, did not confirm these result due to the lower prevalence. In France, the prevalence was assessed with BEWE total score because it is now both the most recommended index and the more recently used, especially in adults $[35,39,41,46,47]$. In children and adolescents, this was only used in a retrospective study [40] and in a study with a population-based sample mixing adults and adolescents [48]. However, three prevalence studies focusing on adolescents [14, 25, 35] have used BEWE scores but with a cutoff value of 1 for DE diagnosis (Table 1). They reported prevalences higher than
$50 \%$, as in our study, and an increase of the prevalence from 39 to $56.8 \%$ by changing the cutoff value (Table 2). There is therefore a problem of both index choice and cut off value, not forgetting the type of tooth wear registered. Studies considering erosion, attrition (wear resulting from tooth to tooth grinding) and abrasion (wear resulting from tooth to other hard surfaces) showed higher prevalences [18, 22, 26, 27] compared with others (Table 1). This could be explained by an easier differential diagnosis in the young population than in the adult one $[2,24,49]$. Finally, the kind of tooth examined influenced the DE prevalence: the examination of maxillary incisors decreased significantly the DE prevalence whereas there was no significant difference between other situations (Table 2). Our results confirm those of other studies, since erosion was found to be greater in posterior than in anterior teeth and the most frequently affected teeth were the lower first molars [2, 3, 16, 17, 22, 31, 33] (Table 3). The most common clinical manifestation of DE was the appearance of cup-like lesions on the cusp tip of lower first molars. By contrast, other studies have recorded DE mainly on anterior teeth $[4,5$, 9-11, 24, 28, 29] where loss of smooth surface enamel is more difficult to see [50]. Yet our examination conditions in schools were optimal due to adequate light and drying facilities. The absence of DE on mandibular incisors in Table 2 is due to their protection from acid attack by the high flow of submandibular saliva [5]. Thus the examination of upper incisors alone and first molars appears sufficient in prevalence studies carried out in adolescents at an age to be fixed by consensus. In the present study, the age of 14 years was used for examination of all teeth due to exposition to possible intrinsinc and extrinsinc aetiological factors for some time; if examining upper incisors and first molars can be considered sufficient, adolescents could be examined at the age of 12. This age should allow both DE prevalence and dental caries to be registered in the same study. Regarding severity, the first degree involving the enamel alone was most common, as has been reported in most of the studies in adolescents $[4-7,10-12,19-21,28,30,32,34$, 49]. To conclude this first part focusing on prevalence, the limitations of the present study should be 
Table 4 Association between erosive experience (total BEWE $\geq 3$ ) and independent variables. Unadjusted and adjusted logistic regression analyses

\begin{tabular}{|c|c|c|c|c|c|c|c|}
\hline \multirow[t]{2}{*}{ Independent variables } & & \multirow[t]{2}{*}{ number } & \multicolumn{5}{|c|}{ Erosive experience (Total BEWE $\geq 3$ ) } \\
\hline & & & No $n(\%)$ & Yes $n(\%)$ & $\begin{array}{l}\text { Unadjusted } \\
\text { OR (95\%) }\end{array}$ & $\begin{array}{l}\text { Adjusted } \\
\text { OR (95\%) }\end{array}$ & $\begin{array}{l}\text { Adjusted } \\
\text { OR (95 \%) }\end{array}$ \\
\hline \multirow[t]{2}{*}{ Socio-economic category } & No PES & 291 & $186(64)$ & $105(36)$ & 1 & 1 & 1 \\
\hline & PES & 40 & $16(40)$ & $24(60)$ & $2.7(1.4-5.2)$ & $2.2(1.1-4.7)$ & $2.2(1.1-4.7)$ \\
\hline \multirow[t]{2}{*}{ Area of residence } & Rural & 17 & $6(35)$ & $11(65)$ & 1 & 1 & 1 \\
\hline & Urban & 314 & $196(62)$ & $118(38)$ & $0.3(0.1-0.9)$ & $0.4(0.1-1.1)$ & $0.3(0.1-1.0)$ \\
\hline \multirow[t]{2}{*}{$\operatorname{Sex}^{1}$} & Female & 174 & $110(63)$ & $64(37)$ & 1 & Not included & Not included \\
\hline & Male & 157 & $92(59)$ & $65(41)$ & $1.2(0.8-1.9)$ & & \\
\hline \multirow[t]{2}{*}{ Dental biofilm } & No visible & 247 & $163(66)$ & $84(34)$ & 1 & 1 & 1 \\
\hline & Visible & 84 & $39(46)$ & $45(55)$ & $2.2(1.4-3.7)$ & $1.8(1.1-3.3)$ & $1.8(1.0-3.1)$ \\
\hline \multirow[t]{2}{*}{ ICDAS 4-6 carious lesions } & No & 285 & $183(64)$ & $102(36)$ & 1 & 1 & Not included \\
\hline & Yes & 46 & $19(41)$ & $27(59)$ & $2.6(1.4-4.8)$ & $1.3(0.6-2.7)$ & \\
\hline \multirow[t]{2}{*}{ ICDAS 1-6 carious lesions } & No & 172 & $118(69)$ & $54(31)$ & 1 & Not included & 1 \\
\hline & Yes & 159 & $84(53)$ & $75(47)$ & $2.0(1.3-3.1)$ & & $1.4(0.9-2.4)$ \\
\hline \multirow[t]{2}{*}{ Fluoride toothpaste ${ }^{c 1}$} & No & 61 & $41(67)$ & $20(33)$ & 1 & Not included & Not included \\
\hline & Yes & 270 & $161(60)$ & $109(40)$ & $1.4(0.8-2.5)$ & & \\
\hline \multirow[t]{2}{*}{ Dentist control during the past year ${ }^{1}$} & No & 73 & $42(57)$ & $31(43)$ & 1 & Not included & Not included \\
\hline & Yes & 258 & $160(62)$ & $98(38)$ & $0.8(0.5-1.4)$ & & \\
\hline \multirow[t]{2}{*}{ Acid reflux/repeated vomiting ${ }^{1}$} & No & 295 & $181(61)$ & $114(39)$ & 1 & Not included & Not included \\
\hline & Yes & 36 & $21(58)$ & $15(42)$ & $1.1(0,6-2.3)$ & & \\
\hline \multirow[t]{2}{*}{ Daily acidic beverage ${ }^{a}$} & No & 270 & $184(68)$ & $86(32)$ & 1 & 1 & 1 \\
\hline & Yes & 61 & $18(29)$ & $43(71)$ & $5.1(2.8-9.4)$ & $3.8(2.0-7.3)$ & $3.6(1.9-7.0)$ \\
\hline \multirow[t]{2}{*}{ Daily energy/sports drinks ${ }^{b} 1$} & No & 326 & $200(61)$ & $126(39)$ & 1 & Not included & Not included \\
\hline & Yes & 5 & $2(40)$ & $3(60)$ & $2.4(0.4-14.5)$ & & \\
\hline \multirow[t]{2}{*}{ Daily aicidic sweets } & No & 299 & $195(65)$ & $104(35)$ & 1 & 1 & 1 \\
\hline & Yes & 32 & $7(22)$ & $25(78)$ & $6.7(2.8-16.0)$ & $2.9(1.1-7.5)$ & $3.0(1.2-7.6)$ \\
\hline \multirow[t]{2}{*}{ Daily acid fresh fruits ${ }^{1}$} & No & 277 & $172(62)$ & $105(38)$ & 1 & Not included & Not included \\
\hline & Yes & 54 & $31(57)$ & $23(43)$ & $1.3(0.7-2.4)$ & & \\
\hline \multirow[t]{2}{*}{ Retained drink in the mouth after drinking } & No & 298 & $189(63)$ & $109(37)$ & 1 & 1 & 1 \\
\hline & Yes & 33 & $13(39)$ & $20(61)$ & $2.7(1.3-5.6)$ & $1.8(0.8-4.2)$ & $1.9(0.8-4.3)$ \\
\hline \multirow[t]{2}{*}{ Daily vitamin C } & No & 298 & $178(60)$ & $120(40)$ & 1 & Not included & Not included \\
\hline & Yes & 33 & $24(73)$ & $9(27)$ & $0.6(0.3-1.2)$ & & \\
\hline
\end{tabular}

All consumers drank acidic beverages during and between meals: $94 \%$ of them were sugared and the most consumed beverages were Cola (89 \%) ${ }^{\mathrm{a}}$ and Powerade $(71 \%)^{\mathrm{b}} .1(9.4 \%)$ or $2(90.3 \%)$ daily tooth brushing ${ }^{\mathrm{c}}$. ICDAS $4-6$ or ICDAS 1-6 carious lesions were included in the adjusted logistic regression analyses. ${ }^{1} \mathrm{p}>0.1$

considered. The study sample was not nationally representative. As the majority of prevalence studies [4-8, 10-12, 16-31, 33-35] (Table 1), it was a stratified sample in a particular area fairly representative of the target population. Thus the application of the results to the French population needs to be confirmed.

Dental erosion is considered a multifactorial condition. Because the present study was cross-sectional and not longitudinal, the design only permitted an analysis of the association between known risk factors and experience of DE in French adolescents to highlight eventual particular cultural behaviors. As in previous studies $[17,24]$, no significant difference in the prevalence of DE between urban and rural areas was found in adjusted logistic regression analyses. Contrary to the majority of the studies $[3,5,8-11,16-18,25,28,33,34]$, socioeconomic status was associated with the experience of DE: the present study confirmed a significantly higher DE prevalence in the lowest social category $[12,24,26$, $32,35,49]$ more often cited than the contrary [7, 23]. The use of different indices could again explain these different results, because the significance of the 
Table 5 Association between erosive experience (total BEWE $\geq 1$ ) and independent variables. Unadjusted and adjusted logistic regression analyses

\begin{tabular}{|c|c|c|c|c|c|c|c|}
\hline \multirow[t]{2}{*}{ Independent variables } & & \multirow[t]{2}{*}{ number } & \multicolumn{5}{|c|}{ Erosive experience (Total BEWE $\geq 3$ ) } \\
\hline & & & No $n(\%)$ & Yes $n(\%)$ & $\begin{array}{l}\text { Unadjusted } \\
\text { OR (95\%) }\end{array}$ & $\begin{array}{l}\text { Adjusted } \\
\text { OR (95\%) }\end{array}$ & $\begin{array}{l}\text { Adjusted } \\
\text { OR (95\%) }\end{array}$ \\
\hline \multirow[t]{2}{*}{ Socio-economic category } & No PES & 291 & $134(46)$ & $157(54)$ & 1 & 1 & 1 \\
\hline & PES & 40 & $9(23)$ & $31(77)$ & $2.9(1.4-6.4)$ & $2.2(1.0-5.2)$ & $2.2(0.9-5.1)$ \\
\hline \multirow[t]{2}{*}{ Area of residence } & Rural & 17 & $4(24)$ & $13(76)$ & 1 & 1 & 1 \\
\hline & Urban & 314 & $139(44)$ & $175(56)$ & $0.4(0.1-1.2)$ & $0.4(0.1-1.4)$ & $0.4(0.1-1.3)$ \\
\hline \multirow[t]{2}{*}{$\operatorname{Sex}^{1}$} & Female & 174 & $78(45)$ & $96(55)$ & 1 & Not included & Not included \\
\hline & Male & 157 & $65(41)$ & $92(59)$ & $1.2(0.7-1.8)$ & & \\
\hline \multirow[t]{2}{*}{ Dental biofilm } & No visible & 247 & $118(48)$ & $129(52)$ & 1 & 1 & 1 \\
\hline & Visible & 84 & $25(30)$ & $59(70)$ & $2.2(1.3-3.7)$ & $1.8(1.0-3.3)$ & $1.7(0.9-3.1)$ \\
\hline \multirow[t]{2}{*}{ ICDAS 4-6 carious lesions } & No & 285 & $132(46)$ & $153(54)$ & 1 & 1 & Not included \\
\hline & Yes & 46 & $11(24)$ & $35(76)$ & $2.7(1.3-5.6)$ & $1.4(0.6-3.1)$ & \\
\hline \multirow[t]{2}{*}{ ICDAS 1-6 carious lesions } & No & 172 & $90(52)$ & $82(48)$ & 1 & Not included & 1 \\
\hline & Yes & 159 & $53(33)$ & $106(67)$ & $2.2(1.4-3.4)$ & & $1.6(1.0-2.47)$ \\
\hline \multirow[t]{2}{*}{ Fluoride toothpaste ${ }^{1}$} & No & 61 & $34(56)$ & $27(44)$ & 1 & 1 & 1 \\
\hline & Yes & 270 & $109(40)$ & $161(60)$ & $1.9(1.1-3.3)$ & $1.9(1.0-3.6)$ & $1.9(1.0-3.7)$ \\
\hline \multirow[t]{2}{*}{ Dentist control during the past year ${ }^{1}$} & No & 73 & $32(44)$ & $41(56)$ & 1 & Not included & Not included \\
\hline & Yes & 258 & $111(43)$ & $147(57)$ & $1.0(0.6-1.7)$ & & \\
\hline \multirow[t]{2}{*}{ Acid reflux/repeated vomiting ${ }^{1}$} & No & 295 & $130(44)$ & $165(56)$ & 1 & Not included & Not included \\
\hline & Yes & 36 & $13(36)$ & $23(64)$ & $1.4(0,7-2.9)$ & & \\
\hline \multirow[t]{2}{*}{ Daily acidic beverage } & No & 270 & $135(50)$ & $135(50)$ & 1 & 1 & 1 \\
\hline & Yes & 61 & $8(13)$ & $53(87)$ & $6.6(3.0-14.5)$ & $4.8(2.1-10.9)$ & $4.5(2.0-10.2)$ \\
\hline \multirow[t]{2}{*}{ Daily energy/sports drinks ${ }^{1}$} & No & 326 & $142(44)$ & $184(56)$ & 1 & Not included & Not included \\
\hline & Yes & 5 & $1(20)$ & $4(80)$ & $3.1(0.3-27.9)$ & & \\
\hline \multirow[t]{2}{*}{ Daily aicidic sweets } & No & 299 & $140(47)$ & $159(53)$ & 1 & 1 & 1 \\
\hline & Yes & 32 & $3(9)$ & $29(91)$ & $8.5(2.5-28.5)$ & $2.9(0.8-10.4)$ & $2.9(0.8-10.5)$ \\
\hline \multirow[t]{2}{*}{ Daily acid fresh fruits ${ }^{1}$} & No & 277 & $124(45)$ & $153(55)$ & 1 & Not included & Not included \\
\hline & Yes & 54 & $19(35)$ & $35(65)$ & $1.5(0.8-2.7)$ & & \\
\hline \multirow[t]{2}{*}{ Retained drink in the mouth after drinking } & No & 298 & $137(46)$ & $161(54)$ & 1 & 1 & 1 \\
\hline & Yes & 33 & $6(18)$ & $27(82)$ & $3.8(1.5-9.6)$ & $2.9(1.1-7.7)$ & $2.9(1.1-7.9)$ \\
\hline \multirow[t]{2}{*}{ Daily vitamin C } & No & 298 & $123(41)$ & $175(59)$ & 1 & 1 & 1 \\
\hline & Yes & 33 & $20(61)$ & $13(39)$ & $0.5(0.2-1.0)$ & $0.5(0.2-1.0)$ & $0.5(0.2-1.1)$ \\
\hline
\end{tabular}

association differed according the indices used in the same study [35]. Indeed socio-economic status had no effect on the dependant variable when a cutoff value of 1 was chosen (Table 5). Sex was not associated with DE prevalence, a result that is in accordance with numerous studies $[4,5,7,9-12,17,18,25,34,35]$. This may be explained by a similar pattern of exposure to risk factors in both sexes. A higher prevalence in males was found more particularly in studies which considered all tooth wear $[22,26,30]$ and it was explained by differences in muscular strength and biting forces [26]. However, others studies targeting only DE found significant differences between the sexes [2, 3, 24, 28, 29, 31, 33] and one study showed a higher prevalence in girls [24].

Concerning oral health, the significantly greater occurrence of DE in the presence of carious lesions ICDAS 1-6 or 4-6 was inconsistent because the relationships were not statistically significant in adjusted logistic regression analyses (Table 4). This is in agreement with different studies using the DMFT (Decayed, Missing, Filled Teeth) index as independent variable [5, 11, 20, 31, 33]. However, caries experience was greater $[25,28]$ or lesser in adolescents with erosive experience [22] according to the studies. These different results could be explained by 
consumption habits of acidic beverages, sugar-free (light) or regular soda drinks. In the present study, this tendency to proportional relationship between carious lesions and DE could be explained by a higher proportion of participants who consumed acid and sugarcontaining cola beverages. The inconsistent relationship between DE and cavitated carious lesions can be explained by the inclusion of visible dental biofilm in one adjusted logistic regression analysis (Table 4). In all cases, the associations were close to statistical significance (Tables 4 and 5). Usually, dental biofilm protects enamel from erosive lesions, especially on anterior teeth. In contrast, the main consumption of both sugary and acidic beverages or sweets in the present study increased the quantity of dental plaque, which was significantly associated with higher DE prevalence. As in other studies [3, 12, 15, 16, 22, 24, 30], no statistically significant association was observed between oral behaviours (daily toothbrushing with fluoride toothpaste, dental examination during the past year) and DE. Only the study of Bardolia et al. [31] showed that a brushing twice a day increased the risk of DE.

Thus, diet plays a major role. In agreement with the majority of studies in adolescents since the 2000s, strong associations were found between $\mathrm{DE}$ and acidic beverages $[6,12,15,17,20,23-25,30,31]$ or sweets $[17,18,23]$ (Table 4). However, the acidic beverage was the sole risk factor to have an effect on the DE, whatever the cutoff value of total BEWE score (Tables 4 and 5). In France, this could be due to a parent education problem about oral health because drinks and food dispensers have been prohibited in schools since 2005. The method of drinking, keeping or not the beverage in the mouth, was also associated with DE $[13,15-17,30]$. Only two studies did not show these associations $[4,11]$. In the present study, the method of drinking had an effect on the DE for a cutoff value of 1 . The frequent behaviour of children of retaining a drink in the mouth could be explained by a particular position of the tongue, the higher DE rates on second premolars compared with first premolars. While there are conflicting results from different studies, the present work confirms the most frequent results for sports drinks $[6,8,9,19,24,29]$, fresh fruits $[6,8,9$, $13,24,31]$ and daily vitamin $C[9,17]$ which were not associated with DE. Only one study (sports drinks; [15]) and four studies (fresh fruits; [17-19, 22]) showed contrary results; in the case of fresh fruits, this concerned only oranges [22], lemon [17] or banana [19]. The present study confirmed that acid reflux and repeated vomiting were not associated with DE in adolescents [9, 11, 14, 24, 29]. Only two studies, both using TWI modified indices (which over assess DE), reported the contrary $[15,16]$. This setting can sometimes be difficult to evaluate due to its subjectivity.

\section{Conclusion}

The DE prevalence in Alpes Maritimes (France) was estimated to reach $39 \%$. It is difficult to compare this estimate with other national prevalences due to the wide range of indices, choice of teeth and age used in different studies. Although the BEWE index has been recommanded, the cut-off value of 1 still needs to be stipulated, for comparison with recent studies. The examination of maxillary incisors and first permanent molars appeared sufficient for assessing DE prevalence. Finally, the age of examination should be discussed because using 12-yearolds would have the advantage of allowing a prevalence study of both DE and caries prevalence.

\section{Abbreviations}

DE: Dental erosion; BEWE: Basic Erosive Wear Examination; AM: Alpes Martimes; PES: Priority education schools; ICDAS: International Caries Detection and Assessment System; TWI: Tooth wear index; DMFT Decayed: missing, filled teeth; OR: Odds ratio; 95 \% Cl: 95 \% confidence interval.

\section{Competing interests}

This study was supported by a grant from the CG06 (Alpes Maritimes) and GABA International. The supporters played no role in data collection and analysis. The authors declare that they have no conflicts of interest.

\section{Authors' contributions}

Some authors have made substantial contributions to conception and design of the study (LLP, MMB), acquisition (TB, MMB) analysis (LLP, MMB) and interpretation of data (FC, VSF, MMB); MMB has been involved in drafting the manuscript; FC and VSF have been involved in revising it critically for intellectual content. All authors read and approved the final manuscript.

\section{Author details}

${ }^{1}$ Dental Faculty, University Nice Sophia Antipolis. CHUN, Nice, France. ${ }^{2}$ URB2i - EA 4462, University Paris Descartes, Montrouge, France. ${ }^{3}$ Dental Faculty, University Paris Descartes, Montrouge, France.

Received: 5 August 2015 Accepted: 9 November 2015

Published online: 19 November 2015

\section{References}

1. Lussi A, Ganss C. Erosive tooth wear from diagnosis to therapy. 2nd ed. Basel: Ed Karger; 2014. p. 278.

2. Arnadottir IB, Holbrook WP, Eggertsson H, Gudmundsdottir H, Jonsson SH, Gudlaugsson JO, et al. Prevalence of dental erosion in children: a national survey. Community Dent Oral Epidemiol. 2010;38(6):521-6.

3. McGuire J, Szabo A, Jackson S, Bradley TG, Okunseri C. Erosive tooth wear among children in the United States: relationship to race/ethnicity and obesity. Int J Paediatr Dent. 2009;19(2):91-8.

4. Correr GM, Alonso RCB, Correa MA, Campos EA, Baratto-Filho F, PuppinRontani RM. Influence of diet and salivary characteristics on the prevalence of dental erosion among 12-year-old schoolchildren. J Dent Child. 2009;76(3):181-7.

5. Auad SM, Waterhouse PJ, Nunn JH, Steen N, Moynihan PJ. Dental erosion amongst 13- and 14-year-old Brazilian schoolchildren. Int Dent J. 2007:57(3):161-7.

6. Waterhouse PJ, Auad SM, Nunn JH, Steen IN, Moynihan PJ. Diet and dental erosion in young people in south-east Brazil. Int J Paediatr Dent. 2008;18(5):353-60.

7. Peres KG, Armênio MF, Peres MA, Traebert J, De Lacerda JT. Dental erosion in 12-year-old schoolchildren: a cross-sectional study in Southern Brazil. Int J Paediatr Dent. 2005;15(4):249-55.

8. Aguiar YPC, dos Santos FG, de Moura EFF, da Costa FCM, Auad SM, de Paiva SM, et al. Association between dental erosion and diet in Brazilian adolescents aged from 15 to 19: a population-based study. Sci World J. 2014;2014:818167. doi:10.1155/2014/818167. 
9. Gurgel CV, Rios D, de Oliveira TM, Tessarolli V, Carvalho FP, de Machado MA. Risk factors for dental erosion in a group of 12- and 16-year-old Brazilian schoolchildren. Int J Paediatr Dent. 2011;21(1):50-7.

10. Gurgel CV, Rios D, Buzalaf MAR, da Silva SMB, Araújo JJ, Pauletto ARC, et al Dental erosion in a group of 12- and 16-year-old Brazilian schoolchildren. Pediatr Dent. 2011;33(1):23-8.

11. Vargas-Ferreira F, Praetzel JR, Ardenghi TM. Prevalence of tooth erosion and associated factors in 11-14-year-old Brazilian schoolchildren. J Public Health Dent. 2011;71(1):6-12.

12. Habib M, Hottel TL, Hong L. Prevalence and risk factors of dental erosion in American children. J Clin Pediatr Dent. 2013;38(2):143-8.

13. Okunseri C, Okunseri E, Gonzalez C, Visotcky A, Szabo A. Erosive tooth wear and consumption of beverages among children in the United States. Caries Res. 2011;45(2):130-5.

14. Alvarez Loureiro L, Fabruccini Fager A, Alves LS, Alvarez Vaz R, Maltz M. Erosive Tooth Wear among 12-Year-Old Schoolchildren: A Population-Based CrossSectional Study in Montevideo, Uruguay. Caries Res. 2015;49(3):216-25.

15. Hamasha AA-H, Zawaideh Fl, Al-Hadithy RT. Risk indicators associated with dental erosion among Jordanian school children aged 12-14 years of age Int J Paediatr Dent. 2014;24(1):56-68.

16. Al-Majed I, Maguire A, Murray JJ. Risk factors for dental erosion in 5-6 year old and 12-14 year old boys in Saudi Arabia. Community Dent Oral Epidemiol. 2002;30(1):38-46.

17. Kumar S, Acharya S, Mishra P, Debnath N, Vasthare R. Prevalence and risk factors for dental erosion among 11- to 14-year-old school children in South India. J Oral Sci. 2013;55(4):329-36.

18. Sanhouri NM, Ziada HM, Ahmed Gl, Kamis AH. Tooth surface loss, prevalence and associated risk factors among 12-14 years school children in Khartoum State, Sudan. Community Dent Health. 2010;27(4):206-12.

19. Huew R, Waterhouse PJ, Moynihan PJ, Kometa S, Maguire A. Dental erosion and its association with diet in Libyan schoolchildren. Eur Arch Paediatr Dent. 2011:12(5):234-40.

20. Huew R, Waterhouse P, Moynihan P, Kometa S, Maguire A. Dental caries and its association with diet and dental erosion in Libyan schoolchildren. Int J Paediatr Dent. 2012;22(1):68-76.

21. Huew R, Waterhouse PJ, Moynihan PJ, Maguire A. Dental erosion among 12 year-old Libyan schoolchildren. Community Dent Health. 2012;29(4):279-83.

22. Abu-Ghazaleh SB, Burnside G, Milosevic A. The prevalence and associated risk factors for tooth wear and dental erosion in 15- to 16-year-old schoolchildren in Amman, Jordan. Eur Arch Paediatr Dent. 2013;14(1):21-7.

23. El Karim IA, Sanhouri NM, Hashim NT, Ziada HM. Dental erosion among 12-14 year old school children in Khartoum: a pilot study. Community Dent Health. 2007;24(3):176-80.

24. Wang $P$, Lin HC, Chen JH, Liang HY. The prevalence of dental erosion and associated risk factors in 12-13-year-old school children in Southern China. BMC Public Health. 2010;10:478

25. Zhang S, Chau AM, Lo EC, Chu C-H. Dental caries and erosion status of 12-year-old Hong Kong children. BMC Public Health. 2014;14:7.

26. Bardsley PF, Taylor S, Milosevic A. Epidemiological studies of tooth wear and dental erosion in 14-year-old children in North West England. Part 1 : The relationship with water fluoridation and social deprivation. Br Dent J. 2004;197(7):413-6

27. Milosevic A, Bardsley PF, Taylor S. Epidemiological studies of tooth wear and dental erosion in 14-year old children in North West England. Part 2 The association of diet and habits. Br Dent J. 2004;197(8):479-83.

28. Dugmore CR, Rock WP. The prevalence of tooth erosion in 12-year-old children. Br Dent J. 2004;196(5):279-82. discussion 273.

29. Arnadóttir IB, Saemundsson SR, Holbrook WP. Dental erosion in Icelandic teenagers in relation to dietary and lifestyle factors. Acta Odontol Scand. 2003:61(1):25-8

30. van Rijkom HM, Truin GJ, Frencken JEFM, König KG, van't Hof MA, Bronkhorst EM, et al. Prevalence, distribution and background variables of smooth-bordered tooth wear in teenagers in the hague, the Netherlands. Caries Res. 2002;36(2):147-54.

31. Bardolia P, Burnside G, Ashcroft A, Milosevic A, Goodfellow SA, Rolfe EA, et al. Prevalence and risk indicators of erosion in thirteen- to fourteen-yearolds on the Isle of Man. Caries Res. 2010;44(2):165-8.

32. Dugmore $C R$, Rock WP. The progression of tooth erosion in a cohort of adolescents of mixed ethnicity. Int J Paediatr Dent. 2003;13(5):295-303.

33. Truin GJ, van Rijkom HM, Mulder J, van't Hof MA. Caries trends 1996-2002 among 6- and 12-year-old children and erosive wear prevalence among 12-year-old children in The Hague. Caries Res. 2005;39(1):2-8.

34. El Aidi $\mathrm{H}$, Bronkhorst EM, Truin GJ. A longitudinal study of tooth erosion in adolescents. J Dent Res. 2008:87(8):731-5.

35. Margaritis V, Mamai-Homata E, Koletsi-Kounari H, Polychronopoulou A. Evaluation of three different scoring systems for dental erosion: a comparative study in adolescents. J Dent. 2011;39(1):88-93.

36. Salas MMS, Nascimento GG, Huysmans MC, Demarco FF. Estimated prevalence of erosive tooth wear in permanent teeth of children and adolescents: An epidemiological systematic review and meta-regression analysis. J Dent. 2015;43(1):42-50.

37. Bartlett DW, Lussi A, West NX, Bouchard P, Sanz M, Bourgeois D. Prevalence of tooth wear on buccal and lingual surfaces and possible risk factors in young European adults. J Dent. 2013;41(11):1007-13.

38. Young A, Amaechi BT, Dugmore C, Holbrook P, Nunn J, Schiffner U, et al. Current erosion indices - flawed or valid? Summary. Clin Oral Investig. 2008;12 Suppl 1:S59-63.

39. Bartlett $D$, Harding M, Sherriff M, Shirodaria S, Whelton H. A new index to measure tooth wear-methodolgy and practical advice. Community Dent Health. 2011;28(2):182-7.

40. Holbrook WP, Arnadóttir IB, Hlöðversson SO, Arnarsdóttir E, Jónsson SH, Sæmundsson SR. The Basic Erosive Wear Examination (BEWE) applied retrospectively to two studies. Clin Oral Investig. 2014;18(6):1625-9.

41. Olley RC, Wilson R, Bartlett D, Moazzez R. Validation of the Basic Erosive Wear Examination. Caries Res. 2014;48(1):51-6.

42. O'Brien M. Children's Dental Health in the UK 1993. London: HMSO; 1994. p. 27-9.

43. Milosevic A, Young PJ, Lennon MA. The prevalence of tooth wear in 14-year-old school children in Liverpool. Community Dent Health. 1994;11(2):83-6.

44. Lussi A, Schaffner M. Progression of and risk factors for dental erosion and wedge-shaped defects over a 6-year period. Caries Res. 2000:34(2):182-7

45. Clara J, Bourgeois D, Muller-Bolla M. DMF from WHO basic methods to ICDAS II advanced methods: a systematic review of literature. Odontostomatol Trop. 2012;35(139):5-11.

46. Bartlett D, Ganss C, Lussi A. Basic Erosive Wear Examination (BEWE): a new scoring system for scientific and clinical needs. Clin Oral Investig. 2008;12 Suppl 1:S65-8.

47. Mulic A, Tveit AB, Wang NJ, Hove LH, Espelid I, Skaare AB. Reliability of two clinical scoring systems for dental erosive wear. Caries Res. 2010:44(3):294-9.

48. Vered Y, Lussi A, Zini A, Gleitman J, Sgan-Cohen HD. Dental erosive wear assessment among adolescents and adults utilizing the basic erosive wear examination (BEWE) scoring system. Clin Oral Investig. 2014;18(8):1985-90.

49. Al-Dlaigan $\mathrm{YH}$, Shaw L, Smith A. Dental erosion in a group of British 14-year-old, school children. Part I: Prevalence and influence of differing socioeconomic backgrounds. Br Dent J. 2001;190(3):145-9.

50. Milosevic A. The problem with an epidemiological index for dental erosion. Br Dent J. 2011;211(5):201-3.

51. Smith BG, Knight JK. A comparison of patterns of tooth wear with aetiological factors. Br Dent J. 1984;157(1):16-9.

52. Millward A, Shaw L, Smith AJ, Rippin JW, Harrington E. The distribution and severity of tooth wear and the relationship between erosion and dietary constituents in a group of children. Int J Paediatr Dent Br Paedodontic Soc Int Assoc Dent Child. 1994:4(3):151-7.

53. Kelly M, Steele J, Nuttall N. Adult Dental Health Survey: Oral Health in the United Kingdom 1998. London: Office for National Statistics.

54. Lussi A. Dental erosin clinical diagnosis and case history taking. Eur J Oral Sci. 1996;104(Part 2):191-8.

55. O'Sullivan EA. A new index for measurement of erosion in children. Eur J Paediatr Dent. 2000;2(1):69-74.

56. Walker A, Gregory J, Bradnock G. National Diet and Nutrition Survey: young people aged 4 to 18 years. Volume 2: Report of the oral health survey 2000. London: The Stationery Office. 